\title{
An Evaluation of Management Perspectives of Sustainability Reporting in the Nigerian Oil Industry
}

\author{
Godfrey Uzonwanne ${ }^{1}$, Kemi Yekini ${ }^{2}$, Sina Yekini ${ }^{3} \&$ Paul Otobo $^{4}$ \\ ${ }^{1}$ University of Chester Business School, University of Chester, United Kingdom \\ ${ }^{2}$ Leicester Business School, De Montfort University, Leicester, United Kingdom \\ ${ }^{3}$ Sheffield Hallam Business School, University of Sheffield, United Kingdom \\ ${ }^{4}$ Glasgow Caledonian University School of Engineering and Built Environment, Caledonian University, United \\ Kingdom \\ Correspondence: Godfrey Uzonwanne, University of Chester Business School, University of Chester, Parkgate \\ Road, Chester, CH1 4BJ, United Kingdom. E-mail: guzonwanne@gmail.com
}

Received: March 3, 2014 Accepted: April 5, $2014 \quad$ Online Published: May 27, 2014

doi:10.5539/jms.v4n2p70 URL: http://dx.doi.org/10.5539/jms.v4n2p70

\begin{abstract}
Purpose: This article investigates the perspectives of managers involved in sustainability reporting in the Nigerian oil industry.

Design/Methodology: The article adopts a survey methodology in its approach to conduct this investigation. The survey employed a structured interview to investigate five themes built around the motivation for sustainability reporting within these organizations, hierarchical responsibility for sustainability reporting, the organizations objectives relative to the welfare of the people within the communities it operates in, policies in place to rejuvenate the damaged environment resulting from it's operations and finally how sufficient in monetary terms is the company's effort to wipe out its operational footprint.
\end{abstract}

Findings: The data gathered was analysed qualitatively under these various themes. The general view emerging amongst the vast majority of the managers interviewed was that oil companies operating within the region have a key social responsibility and disclosure role to play but that it remains the role of the Nigerian Federal Government to provide the institutional framework around which the development of the region is to be hinged.

Research Implications: More research is required in the area of CSR and CSD in developing/emerging markets to understand the link between weak institutional frameworks and voluntary CSR and CSD.

Originality/Value: This article contributes to CSR and CSD literature in broad terms and in specific terms to the literature on sustainable operations in developing/emerging markets. The originality is based on the fact that it explores manager's perspectives in a developing/emerging market.

Keywords: legitimacy theory, sustainability, CSR, CSD, environment, community

\section{Introduction}

\subsection{Statement of Problem}

Crude oil exploration within the Nigerian Niger Delta region accounts for a significant percentage of world consumption of crude oil (3\%) amidst growing accusations by local communities of high levels of environmental degradation resulting from oil exploration activities (Douglas \& Okonta, 2003; Adams, Osho, \& Coleman, 2008) In spite of the claims levelled against foreign multinationals with respect to environmental degradation, Collier (2008) describes a hypothesis he referred to as the natural resource trap. Under this hypothesis, governments of resource rich countries neglect development of other sectors of their economy and concentrate on making fraudulent resource linked gains. Collier argues that this is a major problem linked to why resource rich countries and their citizens remain in the abyss of poverty and environmental degradation. This study explores the perspectives of managers in the Nigerian oil industry with respect to the motive for corporate social responsibility and corporate social disclosure as a means of seeking corporate legitimacy in the Nigerian Niger Delta region. 


\subsection{Importance of Study}

From the Nigerian perspective, Ekineh (2009) is of the view that disclosure by public companies in Nigeria should be made mandatory rather than voluntary and should comply fully with the requirements of the relevant international accounting standards. In his view, Nigerian public companies tend to declare as little as possible thereby calling to question the basis of the organisational legitimacy theory and hence the managerial motive for disclosure in the Nigerian context. This study is therefore leveraging on this gap in the international literature targeted at interpreting the motives of corporate disclosure to examine and evaluate the perspectives of managers in the Nigerian oil industry. The study is exploratory in nature and is novel in its approach as it fills the gap in literature by exploring perspectives of managers of Nigerian oil companies in determining the motive, extent and implication of corporate social disclosure and responsibility of oil companies operating within the Nigerian Niger Delta. It is further novel in its approach and methodology as an exploratory study adopting face to face interviews to seek managerial perspectives within the context of the Nigerian oil industry. It is anticipated that the outcome of this study will serve as a basis for further academic research into corporate social responsibility (CSR) and corporate social disclosure (CSD) within the Nigerian oil industry and will also serve as a prompt for sustainable development and social responsibility by the Nigerian government and oil corporates operating within the depraved delta region.

\subsection{Conceptualization and Theory}

Tavis (1982) highlights how the role of governments in augmenting the efforts of corporations attempting to demonstrate social responsibility and hence legitimacy within their communities impact on improved and sustainable conditions within their communities of operation. While a significant level of criticism has been levelled against multinationals operating within the Nigerian Niger Delta for inadequate social responsibility, Ite (2004) argues that companies such as Shell face the danger of leading development in the region as a result of weak or often non-existent government developmental policy in the depraved region. In emerging markets (such as Nigeria), firm disclosure of profits is often accepted as a vehicle for legitimisation of the firm in the local community as the community harbours expectations of corporate social responsibility on the path of the firm (Prasad \& Green, 2009). Suchman (1995) on one hand is of the view that corporate social responsibility leading to organizational legitimization is a social construct in view of the fact that its validity or benefit to the beneficiary is dependent on the acceptance of the target social audience of the actions of the organization. This acceptance in Suchman's view is a perception which has a long term effect on the image and therefore legitimacy of the organization. Elkington (1997) discussed a framework called 'Triple Bottom Line'. This framework provides an analytical basis for looking at how a company portrays itself responsibly in terms of its social and environmental foot print within its region/community of operation. Adams and Frost (2008) highlight that research into sustainability reporting has often made assumptions of the intentions of corporate entities on the basis of interpretations derived from disclosures in published financial statements without due consideration for the wider implications on the social, political and economic context in which these disclosures are embedded. O'Dwyer (2002) amongst others examines the possibility that the extent of disclosures in publicly available corporate reports is a measure of the legitimacy sought by the companies through the lens of the organisational legitimacy theory.

According to Brundtland (1987), sustainability is defined as the ability of an entity to engage in economic activity today without compromising the ability of future generations to engage in economic activity. A sustainability report is a medium through which management relays the social, environmental and economic impact of their operations to the immediate and wider community in which the impact of its operations is felt. Woodward et al. (2001) and O'Dwyer (2002) argue that managers preparing such reports do so with the intention of conveying a message to the public in an attempt to legitimize the operations of the organization by elaborating broadly on its social and environmental impact. In seeking legitimacy from the public perception of its reporting mechanism, O'Dwyer (2003) illustrates that managers attempt to maintain a balance between the social responsibility of the business and its obligation to its shareholders in a bid to maximise their corporate wealth. Sethi (1979) derived a three stage framework for conceptualizing corporate behaviour breaking down the levels of corporate behaviour along the lines of legitimacy, ethical norms, social accountability, operating strategy, response to social pressure, activities pertaining to governmental actions, legislative/political activities and philanthropy. These levels are tested along the lines of the three stage framework of social obligation, social responsibility and social responsiveness. The framework demonstrates that organizations recognise their obligations and responsibilities to society and ultimately expect that society responds to their actions in a bid to seek some form of legitimization. This nature of strategic framework described by Sethi towards legitimization is further supported by Deephouse (1996). Azzone et al. (1997) examine the drivers of environmental reporting 
from the perspective of stakeholders and conclude that corporate reports are used as a means of communicating the company's concern towards the environment to its various stakeholders as well as demonstrating a degree of openness towards the shareholder. This view expressed by Azzone et al can rightly be argued to be that companies use disclosure in their annual reports as a means of seeking legitimacy. This disclosure is targeted at outsiders as well as insiders (not involved in the decision making process of the company). Delmas and Toffel (2004) are however of the view that organisations particularly those voluntarily reporting above the required disclosure level do so under institutional pressure which implies that seeking legitimacy is forced upon them rather than a voluntary choice.

Various studies test the basis of the legitimacy theory as a framework for analysing the reason behind management actions both in operations and disclosures. Deegan et al. (2002), O'Donovan (2002), Deephouse and Carter (2005) and Barkmeyer (2007) provide empirical evidence to illustrate that disclosures in corporate reports are primarily driven by the desire to legitimise the corporation's social image in the context of its operational impact on the society and environment.

\subsection{Relationship to Other Studies}

Other studies such as Benoit (1997), Benoit and Brinson (1999), Liu (2007), Benoit and Henson (2009), Grant et al. (2010) and Yekini and Jallow (2012) describe organisational legitimacy as a tool used by organizations to repair their image if and when they fall short of societal expectations of their operations in the society. For instance, Yekini and Jallow (2012), adopting a signalling theory approach, provided empirical evidence to illustrate the fact that CSR disclosures signal response to societal expectation. Similarly and Patten (2002), Tregidga (2007) and Lima de Queiroz et al. (2007), emphasis the role of the environment in legitimising an organisation's activities. Organisations that actively report on how their operations affect the environment and what efforts they make to reverse their environmental footprint in effect seek legitimacy from society. Tilling (2004), Lamberton (2005) and Queiroz (2007) follow an institutional theory approach to analyse the impact of organizational legitimacy on the broader community; organizations from the institutional perspective seek legitimization as a means of making their activities appear natural and beneficial to society.

\section{Method}

This study followed an exploratory approach to evaluate the views of managers in the Nigerian oil industry in relation to their company's sustainability reporting framework. The exploration was conducted in the light of companies seeking corporate social legitimacy as a motive for corporate social disclosure and responsibility. O'Dwyer (2002) examined the motives for corporate social disclosure in Irish companies through the lens of the organisational legitimacy theory using interview based evidence to seek the perspectives of managers charged with preparing these disclosures. O'Dwyer (2003) following the same interview based research method used in O'Dwyer (2002) extends the examination of managerial conceptions of corporate social responsibility in the Irish context. A similar interview based framework was adopted by Adam and Frost (2008) to investigate the integration of sustainability reporting into management practices across three Australian and four British companies.

Because of the security sensitivity of the Nigerian Niger Delta (the oil drilling region of the country), extreme care was taken in conveying the purpose of the research and interviews to the respondents who were sceptical about the purpose of the exercise and therefore needed constant reassurance that the exercise was governed primarily by academic interest. Gathering of data was carried out via intensive face to face interviews across four major oil drilling companies with a total of twenty respondents participating in the study (five respondents per company). In order to get the respondents to participate in the interviews, complete anonymity was guaranteed upfront through our contacts. Anonymity was essential due to the sensitivity of the questions this semi-structured interview process sought to address. The social context of the interviews was one that had faced a significant amount of unrest over the last four decades as a result of views of deprivation and national neglect held by members of the local communities. With the confirmation of anonymity, a free flowing interview process emerged. The interviews were conducted between August and September, 2011.

The interview questions were structured around the "Triple Bottom Line" framework developed in Elkington (1997) with a view to guide the respondents to deliver specific answers to certain questions which formed the basis of the framework of the data required. Beyond the structure of the interview questions however, the respondents were allowed a free flowing process to discuss their views thereby giving the overall interview a free flowing semi-structure.

The interview targeted Senior Executives in four oil companies operating within the Nigerian Niger Delta Region. The choice of respondents was to ensure that the respondents were actively involved in the decision 
making process of their various companies. Again, in order to assuage any feelings of encroachment as a result of the dire security situation surrounding Nigerian oil companies, a letter of introduction was forwarded through each of our contacts to the respondents outlining the interviewer's institutional affiliation and contact details, purpose of the interview, a summary literature review to demonstrate the broad academic interest in corporate social responsibility and disclosure and a sample of the interview questions with a clear indication that the interviewer was not seeking industry based opinion but rather their personal view of the questions sought to be addressed.

The interviewees enjoyed the interview sessions and demonstrated an unexpected willingness to engage in the interview and air their perspectives. The eagerness demonstrated by some of the respondents suggested that they may have bottled up views within them for a substantial amount of time. The general feeling with a substantial number of the interviewees was that they were pleased to air their views amidst security concerns.

\section{Thematic Analysis and Interpretation of Results}

The validity, reliability and generalizability of field data has always been a huge source of concern for social researchers who adopt qualitative methods to theorize on various aspects of human, organizational and institutional behaviour (McKinnon, 1988; Lillis, 1999; Bryman \& Bell, 2007). Field data must therefore engage in intense rigor and detailed reporting to ensure that the target audience can adjudge the quality and reliability of the study (McKinnon, 1988; Woodward et al., 2001; O'Dwyer, 2002)

For the purpose of this analysis, the four companies would be referred to as companies A, B, C and D. The various respondents from each company such as company $\mathrm{A}$, would be referred to as respondent A1, A2, A3, A4 and A5; respondents from company B would be referred to as respondent B1, B2, B3, B4 and B5; respondents from company $\mathrm{C}$ will referred to as $\mathrm{C} 1, \mathrm{C} 2, \mathrm{C} 3, \mathrm{C} 4$ and $\mathrm{C} 5$ and respondents from company $\mathrm{D}$ will be referred to as D1, D2 D3, D4 and D5. Adams and Frost (2008) follow a similar labelling technique and methodology.

Following Elkington (1997), the structured interview questions were outlined under six themes; these themes were motivation for sustainability reporting, responsibility hierarchy for sustainability reporting, people, planet, profits and general views. Several questions were asked under each theme (see appendix for questions) while respondents were allowed to carry on discussing each question whenever it was felt that they hadn't properly addressed the question.

\subsection{Motivation for Sustainability Reporting}

The executives from all four oil companies broadly identified that their company's disclosure was primarily focused on the environment, engagement with their operating and neighbouring communities as well as safety of operations amongst other forms of disclosure. Sustainable development they mostly argued was at the cutting edge of their company's vision not only at present but into the distant future. All twenty executives interviewed emphasised that their companies were sincerely motivated to sustainable operations and sustainability reporting. They all felt that their various companies were committed to sustainability reporting/disclosure driven by a genuine interest to protect the environment and their operating communities. There was a general consensus amongst all the officers interviewed that the business of oil exploration was one that was very damaging to the environment and indeed the welfare of indigenes of their operating communities. One of the respondents, fairly senior in hierarchy in his company said: "Tell me how you will play a football match in the rain without getting wet? The important thing is that after the football match, we wash our gear and dry them properly so they do not pick up a bad smell. That's the picture of sustainable operations, our operations will always leave some damage, the important thing is how well we address the damage to reduce its impact on the community and environment. This is a priority for us in company B but with the obvious institutional problems here in Nigeria, how easy is it to achieve this goal?". This echoes the views highlighted in Patten's (1992) findings that corporations are committed to responding to legitimacy-threatening events as was the case in Alaska oil spills; however, there seems to be some constraints within the Nigerian context.

In spite of the commitment to sustainable practice in their operational environments, some respondents such as A4, C1, C2 and D2 were of the view that their companies and indeed the entire oil industry was simply not doing enough to tackle the environmental degradation within the Nigerian Niger delta region. They argued that since their companies were aware that a significant proportion of oil spillages within the delta region was as a result of theft and deliberate damage by local gangs, the responsibility of managing sustainability of their operating environment did not rest solely with the oil companies operating within the region but was also extended to the Nigerian government. In their view, the Nigerian government was as much a player in the oil exploration as they were and so believed that the government to whom they paid taxes and royalties should provide the enabling environment for them to control oil spillages resulting from deliberate damage to oil facilities and infrastructure. 
About $65 \%$ of the executives interviewed based their definition of sustainability reporting on aspects related to their operating environment and the welfare of communities existing around the areas of operation. The remaining $35 \%$ extended this definition to include broader issues such as their organisation's economic impact and governance structures. Two executives from company B (B2 and B3) mentioned the Global Reporting Initiative (GRI) and GRI Sustainability Reporting Guidelines as a reliable benchmark to evaluate the extent of a company's compliance with sustainability reporting standards but also pointed out that these guidelines were difficult to meet in an operating environment as complex as the Nigerian environment. Respondent B2: "I don't need to tell you that all this big grammar is useless in Nigeria...Laughs out Loud... I am sure you understand what I mean..". This broadly refers to the difficulty of regulatory enforcement which is traditionally experienced in the Nigerian business climate. The emerging theme here therefore was that these companies were eager to operate in a sustainable manner but were generally hampered by constraints imposed on them by the peculiar political and social environment in which they carried out their operations.

In view of the fact that most of the disclosures on sustainability engaged in by these companies were voluntary, the respondents identified three main audiences that their disclosure was targeted at in the following order of importance: the international community, the Nigerian community and the Nigerian government. More than $50 \%$ of the respondents openly stated that disclosure targeted at the Nigerian government was not important as the government as an institution was not making enough effort to institute a permanent solution to the Niger Delta crisis. Respondent D3 stated "most oil companies operating in the delta region and certainly company D have a good intention however when faced with external governance structures, rife with corrupt officials, most companies just follow the rule of the game. The problem of environmental degradation in the Nigerian Niger Delta region can only be permanently solved by government intervention to support oil companies to play their part in full, through honest disclosures".

Respondents felt that the direct cost of disclosure was significantly less than the overall benefits of disclosure. Approximately $22 \%$ of the respondents felt that full disclosure within the Nigerian Niger Delta region was also associated with other indirect costs such as political and social costs. A substantial number of these $22 \%$ felt it was not their role to discuss further on the political and social costs. Respondent D1 said "you know what I mean by political costs, we are here to do business not tell the government how to run their country, let's move on to something else". This view expressed by this respondent ultimately suggests that what the government does is none of their business as corporate entities. While they would like the government to take the lead and provide the institutional framework for effective sustainable operations, it is apparent that this is not high up on the government's agenda so they, as corporate entities must concentrate on their agency responsibilities to their shareholders while attempting to do their best towards stakeholder interest.

All the respondents reaffirmed that their companies pay equal attention to the community, the environment, product quality and profit but because of the extent of environmental degradation within the Niger delta region, the focus of their managements was mostly on the community and environment as these two themes pose an immediate danger to the lives of habitants within these communities and consequently, on the overall corporate objectives of the companies. Mitchell et al. (1997), using the stakeholder identification and salience model argued that the neglect of these two themes can undermine the achievement of the overall corporate objectives.

\subsection{Responsibility Hierarchy for Sustainability Reporting}

Within all four companies, the managers interviewed quite clearly stated that sustainability reporting within their organizations was a high priority of senior management. Sustainability reporting teams followed laid down guidelines from their mother companies (in the case of multinational companies within the groups interviewed) and thus was of very dire interest to the company's top hierarchy. The data used to prepare these reports were gathered from field reports, dialogue with community heads, spot checks by specially designated teams, risk assessment reports, government reports and opinion polls. Some of the managers particularly from company $\mathrm{C}$ were of the view that the final report published by oil companies operating within the region bore no close resemblance to the physical state of the region. Respondent C3 stated: "It will take a major clean-up operation to restore this region to anything near sustainable! The problem now is, whose responsibility is it to finance such a major clean-up operation? Is the Nigerian government even willing to look into this possibility? My view is that such a clean-up operation should be effected, followed by improved security of oil facilities and tighter monitoring of and enforcement of regulations. Some oil companies hide behind the poor institutional framework to operate in rather poor conditions because there is no one to check on them or at least they know how to get out of the noose when they fall into it..." There is a clear suggestion here of poor enforcement and the possibility of bribery as a more suitable lower cost alternative to regulatory compliance. Respondent A1 highlighted that 
reports produced by his company ultimately toned down the extent of environmental hazard represented by the Nigerian Niger Delta.

Under this theme, there was an obvious willingness expressed by the respondents to seek corporate social legitimacy through the lens of CSR and CSD. There was however an overwhelming feeling of rejection ensuing from the fact that this was not always possible due to institutional failures on the path of the government (See Mitchell et al. (1997).

\subsection{People}

All the managers interviewed did not think that the operation of their companies within the Niger delta region was beneficial to the local community. A few of the managers (A1, B4, C1, C2, and D3) felt that their activities were indeed exploitative of the local community. Manager D3 stated "the delta region has continued to recede in poverty from year to year in spite of the vast amount of oil wealth extracted annually from the region. Our company obviously has social schemes for the people of the region such as health care schemes, educational schemes and employment opportunities available to local indigenes but this is really nothing compared to the amount of money we extract annually from the region, it is just peanuts to give the impression that the company is a social actor".

All the managers interviewed re-iterated the fact that acts of corporate social responsibility could only ride on the back of a well-meaning government driven plan. Much as the companies were willing to be benevolent and extend assistance to the communities as they were already engaged in, the managers felt that the efforts of corporate entities operating within the region were lost within the vast amount of social and developmental issues the region has been grappling with over the last four decades. Respondent B1 stated: "As much as we as oil corporates have an undeniable responsibility towards our operating communities and environment, the role of the government here in the Niger delta cannot be undermined. Look all around you, be sincere to yourself, where will our efforts start from? This region requires a solid government led intervention to restore it. Mistakes have been made in the past, my view is that we focus on the future... in other parts of the world, it is the government that creates the enabling environment for sustainable operations". Respondents were of the view that the scale of degradation in the Niger delta was so immense that its reversal was down to institutional intervention and beyond the effective remit of corporate social responsibility. This can however, provide support for the arguments by Campbell (2000) and Parker (2005) that legitimacy theory is defective in explaining managerial behaviour in full. Here Managers are willing and committed to sustainable development but handicapped by lack of institutional framework.

\subsection{Planet}

Response to the questions under this theme was fairly uniform. Each group of managers stated that their companies followed internationally accepted general practice to deal with environmental issues associated with their operations such as oil spillages which remains a major catastrophe within the Nigerian Niger delta region. They acknowledged that the current Nigerian government's amnesty deal with the militant groups operating within the Niger delta region had contributed strongly to improving the security situation within the delta region and hence a marked reduction in criminal oil spillage was apparent. The respondents collectively felt that their various companies still had a significant amount of work to be done in order to improve the environmental conditions of their operational environment and by extension the welfare of their operational communities. In their opinion however, there were significant constraints arising from vandalizing of facilities by members of local communities that made their efforts so much more difficult.

When asked about the long term health prospects of communities situated within the catchment areas of their operation, the response was unanimous. The Nigerian Niger delta region is indeed a hazardous environment for habitation of humans, flora and fauna due to the massive levels of oil spillages that have remained on the waters and sipped into the soil over extensive periods of time. The short and long term health prospects of these communities are indeed very poor. Did they feel the Nigerian government was working positively towards addressing these health hazards? Some respondents simply laughed and asked that we move to the next question while others said "you can see for yourself, what do you think?". In the characteristic cultural manner, such a rhetoric question implies a laughable "No". With the amount of oil residues still actively floating on the Nigerian Niger Delta waters, there is little doubt that the health of communities in the region is not of the essence to government agencies. Mitchell et al. (1997) and Yekini (2012) clearly substantiate these views by highlighting the realities of the difficulties associated with ensuring that a company's operations are fully compliant with all relevant environmental standards. 


\subsection{Profits}

Caution was exercised under this theme as none of the managers interviewed was sufficiently senior in hierarchy to determine the percentage of total profits dedicated to social responsibility. The general opinion expressed here however was that activities such as mopping of oil spillages were dealt with as they occurred so these could not be budgeted for quite so easily. Other social activities such as provision of local services such as health care, good roads, portable water supply etc. is provided for as the need is identified. These decisions in all four companies were made at a rather senior level within the companies. Respondent D3 reiterated that "in my view, the oil companies operating in the region have destroyed the welfare of the environment of the Niger delta due to both the direct and indirect impact of their activities. Are they currently investing enough to reverse this damage? I don't think so! Look at the damaged roads, the aquatic life, the water supply before we start talking of health care, schools and provision of employment opportunities for the indigenes! No, all the companies operating in this region simply take advantage of the poor government initiative and put up some cheap programmes just to fulfil international reporting standards". The literature presents conflicting schools of thought on the issue of returning profits to reverse the impact of a company's operations of the environment. Following Friedman (1970), the social responsibility of an entity is to maximise the wealth of its shareholders. Other arguments in favour of stakeholders such as Clarkson (1995) and Moon and Muthuri (2006) support the findings from our respondents who are of the view that companies operating within the delta region should return more of their profits to the environment to ensure that their operational foot prints are sufficiently wiped out.

\subsection{General Views/Summary}

In summary, the managers interviewed broadly acknowledged that their various companies had one programme or the other targeted at social responsibility towards their local communities. They also agreed that their companies were involved actively in environmental disclosure and had programmes targeted at enhancing the welfare of local communities. They however argued that the federal government of Nigeria was ultimately responsible for the development of the region and not the oil companies. Their role was purely supportive and contributory while the broad framework was to be provided by the federal government. A major problem highlighted by all the managers as setting the region back was that of theft and damage to oil facility by the local indigenes themselves.

\section{Implication of Results}

The interview adopted the concept of the triple bottom line to explore the motive of some Nigerian oil companies for corporate social responsibility and corporate social disclosure as a means of seeking corporate legitimacy. The central thesis of Elkington (1997) is based on the argument that corporate entities should direct the energies towards the maximization of stakeholder benefits rather than the traditional shareholder wealth maximization view held by most businesses. The interviews were therefore geared towards exploring the commitment of oil companies operating within the Nigerian Niger Delta towards stakeholder responsibility. While the managers interviewed leaned towards a stakeholder perspective, they unanimously agreed that the central responsibility for sustainable development and governance of the region was that of the federal government rather than the oil companies who ultimately were tax payers. Friedman (1970) quite clearly highlighted the various roles and responsibilities of governments and corporate entities towards the welfare and development of communities. Friedman argued that as long as corporate entities paid their taxes promptly as set out by government agencies, then corporate entities had no obligation towards benevolent community endeavours as their sole responsibility under a principal-agent relationship was to their shareholders. Managers therefore diverting their shareholders funds towards community oriented goals were in fact stealing from their shareholders.

On the basis of Freidman's argument, and in relation to the Nigerian Niger delta, it is the sole responsibility of the government to ensure that adequate processes, legislation and enforcement are employed in oil exploration, drilling and transporting by the oil companies licensed to operate within the delta region. Other issues such as health care of local communities, provision of good roads, schools, jobs and other social facilities and amenities also primarily fall at the doorstep of the Federal Government of Nigeria. In order to achieve these onerous goals, the Federal Government must roll out an adequate development plan to meet these demands and subsequently, on the basis of these plans arrive at a reasonable tax structure to compensate the local communities for environmental degradation associated with oil exploration within the region. The structure should be seen to ensure that future generations are able to pursue social and economic activities in the region unhampered by current explorations. 
Notwithstanding Friedman's (1970) position, it is the argument of this article that companies should be committed to sustainable development within their area of operation as argued by the proponents of the stakeholder theory such as Clarkson (1995); Donaldson and Preston (1995); Mitchell et al. (1997); Altman (2000); Moon and Muthuri (2006) and Yekini (2012). These scholars argued that corporate entities should play an active role in the restoration of their operating environment above and beyond charitable donations. Delmas and Toffel (2004) following an institutional approach to stakeholder engagement analyse the role of corporate entities in environmental disclosure and community management programmes beyond the statutory disclosure and engagement requirement and conclude that corporate entities are often under undue pressure from government agencies to go the extra mile often picking up responsibilities beyond their obligation. These extra responsibilities as seen from the outcome of the survey just concluded in the view of managers, fall within the remit of government responsibility.

\section{Conclusion}

The primary purpose of this article was to explore the perspectives of managers working within the Nigerian oil industry which has had a long standing reputation for environmental degradation. The study adopted the framework of the 'Triple Bottom Line' to explore manager's views on corporate social disclosure and corporate social responsibility. The uniqueness of this study is in the fact that it employed the perspectives of senior managers within the Nigerian oil industry to understand the motives and problems of corporate social disclosure and responsibility within the oil exploration zone. The framework introduced in Elkington (1997) was adopted to explore these motives and problems through the lens of the organizational legitimacy theory. From the foregoing survey, it is quite clear that sustainability reporting amongst oil companies operating within the Nigerian Niger Delta is currently an issue that remains high up on the agenda of corporate social disclosure. These companies from the perspectives of their management staff are indeed keen to seek social legitimacy by their expressed desire to operate within internationally accepted sustainable environmental standards but claim that their efforts are undermined by a poor or perhaps non-existent governmental institutional framework. This finding is in line with the motives for corporate social disclosure identified in Yekini and Jallow (2012).

The perspectives gathered therefore point to the fact that the oil companies operating within the Nigerian Niger Delta region believe that they do have a role to play in ensuring that the welfare of communities within their catchment area is maintained as a priority. These managers further believe that their roles should augment the efforts of the government rather than replace it. This further sheds light on the true objective of the firm as an entity, the role of managers as agents and their primary responsibility to shareholders and stakeholders alike (Friedman, 1970). In an industry like the oil exploration industry, it is difficult to suggest that accidents resulting in environmental degradation can be completely taken care of by the exploring companies. In the Nigerian Niger Delta, the issue of deliberate damage resulting in huge volumes of leakage indeed makes it difficult to begin to rationalise the premise for these oil companies to conduct sustainable exploration and contribute to social welfare. Attempting to trace the source of vandalism back to its roots advertently opens up several other institutional issues which fall squarely within the remits of the Federal Government of Nigeria.

Nevertheless, this by no means, represents a justification for the oil companies to continue to turn their eyes away from the degradation associated directly or indirectly with their exploration. The key question that inevitably arises is that of separation of mandatory responsibility from benevolence. This divide is amplified in academic literature by strands of arguments in favour of the fact that businesses should operate in the sole interest of their shareholders (Friedman, 1970) versus an allocation of interest across a broader spectrum of stakeholders (Mitchell et al., 1997; Altman, 2000; Ite, 2004; Yekini, 2012). Altman (2000) asserted that the corporation's responsibility to its community includes the improvement of the quality of life in cities and towns for its employees and for the catchment area around its field of operation and potentially, for the groups or individuals that could be harmed by its operations. Mitchell et al. (1997) describe this group as "coercive and possibly violent" (p. 877); while Yekini (2012) argued that ignoring this group of community stakeholders will impact negatively on the corporation.

The foregoing are pointers to the crisis, vandalism, kidnapping and so on, which have characterised the Nigerian Niger Delta region in the last four decades. A reasonable level of stability has however been restored as a result of the present 'Goodluck Jonathan' led Nigerian government engaging with key leadership figures amongst the militant groups in the Niger Delta region. Some of the managers interviewed however viewed this as a temporary response to a severely deep crisis which deserves a much more long term solution. While this engagement has abated the worst of the crisis, fundamental regional development issues capable of restoring lasting peace and stability to the region have been ignored or engaged with in a very bureaucratic and un-purposeful manner. 
The views and perspectives expressed in this article were gathered from 20 senior managers currently working for oil companies within the Nigerian Niger Delta. Much as these views have formed the basis of the argument within this article, there is need to re-iterate that the views expressed are personal to them and may not necessarily represent the overall position of the management of their companies. To this end, the managers required a strong guarantee of anonymity to secure their participation in the survey. Overall, the results and views discussed have severe implications for the broader understanding of the environmental, social and political problems of the Nigerian Niger Delta and hence the building of institutions capable of channelling a lasting solution to the four decade long crisis the region has so become accustomed to.

Finally, this article highlights objectives for the Nigerian government to pursue in ensuring that the footprint of oil exploration in the region is effectively wiped away to ensure that future generations are able to pursue their social, political and economic affairs successfully (Brundtland, 1987). The welfare of electorate resident within the catchment area of the oil exploration is indeed of significance.

\section{References}

Adams, C. A., \& Frost, G. R., (2008). Integrating Sustainability Reporting into Management Practices. Accounting Forum, 32, 288-302. http://dx.doi.org/10.1016/j.accfor.2008.05.002

Adams, M., Osho, G., \& Coleman, Q. (2008). The Politics and Political Implications of Oil and Gas Exploration in Africa: An Analysis of American Oil Corporations in Nigeria. International Business and Economics Research Journal, 7(12), 107-116.

Altman, B. W. (2000). Defining 'Community As Stakeholder' and Community Stakeholder Management: A Theory Elaboration Study. In Research in Stakeholder Theory 1997-1998, Clarkson Centre for Business Ethics. University of Toronto, Toronto.

Azzone, G., Brophy. M., Noci, G., Welford, R., \& Young, W. (1997). A Stakeholders' View of Environmental Reporting. Long Range Planning, 30, 699-709. http://dx.doi.org/10.1016/S0024-6301(97)00058-7

Barkmeyer, R. (2007). Legitimacy as a Key Driver and Determinant of CSR in Developing Countries. Paper for the 2007 Marie Curie Summer School on Earth System Governance, 28 May-06 June 2007, Amsterdam.

Benoit, W. L. (1997). Image Repair Discourse and Crisis Communication. Public Relations Review, 23(2), 177-186. http://dx.doi.org/10.1016/S0363-8111(97)90023-0

Benoit, W. L., \& Brinson, S. (1999). Queen Elizabeth's Image Repair Discourse: Intensive Royal or Compassionate Queen. Public Relations Review, 25(2), 145-156. http://dx.doi.org/10.1016/S0363-8111(99)80159-3

Benoit, W. L., \& Henson, J. R. (2009). President Bush's Image Repair Discourse on Hurricane Katrina. Public Relations Review, 35(1), 40-46. http://dx.doi.org/10.1016/j.pubrev.2008.09.022

Brundtland Commission. (1987). Our Common Future. Oxford: Oxford University Press.

Bryman, A., \& Bell, E. (2007). Business Research Methods. Oxford: Oxford University Press.

Campbell, D. J. (2000). Legitimacy Theory or Managerial Reality Construction? Corporate Social Disclosure in Marks and Spencer Plc. Corporate Reports, 1969-1997. Accounting Forum, 24(1), 80-100. http://dx.doi.org/10.1111/1467-6303.00030

Clarkson, M. E. (1995). A Stakeholder Framework for Analysing and Evaluating Corporate Social Performance. Academy of Management Review, 20(1), 92-117.

Collier, P. (2008). The Bottom Billion-Why the Poorest Countries are Failing and What Can Be Done about It. Oxford University Press.

Deegan, C., Rankin, M., \& Tobin, J. (2002). An Examination of the Corporate Social Disclosures of BHP from 1983-1997. Accounting, Auditing and Accountability Journal, 15(3), 312-343. http://dx.doi.org/10.1108/09513570210435861

Deephouse, D. L. (1996). Does Isomorphism Legitimate? Academy of Management Journal, 39(4), 1024-1039. http://dx.doi.org/10.2307/256722

Deephouse, D. L., \& Carter, S. M. (2005). An Examination of Differences between Organizational Legitimacy and Organizational Reputation. Journal of Management Studies, 42(2). http://dx.doi.org/10.1111/j.1467-6486.2005.00499.x 
Delmas, M., \& Toffel, M. W. (2004). Stakeholders and Environmental Management Practices: An Institutional Framework. Business Strategy and the Environment, 13, 209-222. http://dx.doi.org/10.1002/bse.409

Donaldson, T., \& Preston, L. E. (1995). The Stakeholder Theory of the Corporation: Concepts, Evidence and Implications. Academy of Management Review, 20(1), 65-91.

Douglas, O., \& Okonta, I. (2003). Where Vultures Feast: Shell, Human Rights, and Oil in the Niger Delta. San Francisco: Sierra Club Books.

Ekineh, D. (2009). Reform Agenda for Corporate Governance in Nigeria: Disclosure and Reporting Requirement. Paper Presented at the Institute of Directors Corporate Governance Workshop in Lagos, Nigeria.

Elkington, J. (1997). Cannibals with Forks: The Triple Bottom Line of $21^{\text {st }}$ Century Business. Oxford: Capstone.

Freidman, M. (1970). The Social Responsibility of Business is to Increase Its Profits. New York Times Magazine, September.

Ite, U. E. (2004). Multinationals and Corporate Social Responsibility in Developing Countries: A Case Study of Nigeria. Corporate Social Responsibility and Environmental Management, 11, 1-11. http://dx.doi.org/10.1002/csr.49

Lamberton, G. (2005). Sustainability Accounting-A Brief History and Conceptual Framework. Accounting Forum, 29, 7-26. http://dx.doi.org/10.1016/j.accfor.2004.11.001

Lillis, A. M. (1999). A Framework for the Analysis of Interview Data From Multiple Field Research Sites. Accounting and Finance, 39, 79-105. http://dx.doi.org/10.1111/1467-629X.00018

Lima de Queiroz, M. A., Carcalho de Vasconcelos, F., \& Goldszmidt, R. G. (2007). Economic Rents and Legitimacy: Incorporating Elements of Organizational Analysis Institutional Theory to the Field of Business Strategy. Brazilian Administration Review, 4(1), 51-65.

Liu, B. F. (2007). President Bush's Major Post-Katrina Speeches: Enhancing Image Repair Discourse Theory Applied to the Public Sector. Public Relations Review, 33(1), 40-48. http://dx.doi.org/10.1016/j.pubrev.2006.11.003

McKinnon, J. (1988). Reliability and Validity in Field Research: Some Strategies and Tactics. Accounting, Auditing and Accountability Journal, 1(1), 34-54. http://dx.doi.org/10.1108/EUM0000000004619

Mitchell, R. K., Agle, B. R., \& Wood, D. J. (1997). Toward a Theory of Stakeholder Identification and Salience: Defining The Principle of Who and What Really Counts. Academy of Management Review, 22(4), 853-886.

Moon, J., \& Muthuri, J. N. (2006). An Evaluation of Corporate Community Investment in the UK: Current Developments, Future Challenges. A Report of Charities Aid Foundation, United Kingdom.

O'Donovan, G. (2002). Environmental Disclosures in the Annual Report-Extending the Applicability and Predictive Power of Legitimacy Theory. Accounting, Auditing and Accountability Journal, 15(3), 344-371. http://dx.doi.org/10.1108/09513570210435870

O’Dwyer, B. (2002). Managerial Perceptions of Corporate Social Disclosure-An Irish Story. Accounting, Auditing and Accountability Journal, 15(3), 406-436. http://dx.doi.org/10.1108/09513570210435898

O'Dwyer, B. (2003). Conceptions of Corporate Social Responsibility: The Nature of Managerial Capture. Accounting, Auditing and Accountability Journal, 16(4), 523-557. http://dx.doi.org/10.1108/09513570310492290

Parker, L. D. (2005). Social and Environmental Accounting Research: A View from the Commentary Box. Accounting, Auditing and Accountability Journal, 18(6), 824-860. http://dx.doi.org/10.1108/09513570510627739

Patten, D. (1992). Intra-Industry Environmental Disclosures in Response to the Alaskan Oil Spill: A Note on $\begin{array}{llll}\text { Legitimacy Theory. Organisations and } & \text { Society, } 475 .\end{array}$ http://dx.doi.org/10.1016/0361-3682(92)90042-Q

Patten, D. M. (2002). The Relation between Environmental Performance and Environmental Disclosure: A Research Note. Accounting, Organizations and Society, 27, 763-773. http://dx.doi.org/10.1016/S0361-3682(02)00028-4

Prasad, A., \& Green, P. (2009). Profit and Organisational Legitimacy in Emerging Markets. Conference Paper, 2009 Afannz Conference Adelaide. 
Samkin, G., Allen, C., \& Wallace, K. (2010). Using Annual Reports to Repair Organisational Legitimacy: The Case of the New Zealand Police. Open Conference 2010.

Sethi, S. P. (1979). A Conceptual Framework for Environmental Analysis of Social Issues and Evaluation of Business Response Patterns. Academy of Management Review, 4, 63-74.

Suchman, M. C. (1995). Managing Legitimacy: Strategic and Institutional Approaches. Academy of Management Review, 20(3), 571-610.

Tavis, L. A. (1982). Multinational Corporate Responsibility for Third World Development. Review of Social Economy, 40(3), 427-437. http://dx.doi.org/10.1080/00346768200000043

Tilling, M. V. (2004). Refinements to Legitimacy Theory in Social and Environmental Accounting. Commercial Research Paper Series No. 04-6.

Tregidga, H., Milne, M., \& Kearins, K. (2007). Organizational Legitimacy and Social and Environmental Reporting Research: The Potential of Disclosure Analysis. Asia Interdisciplinary Research in Accounting Conference, Auckland.

Woodward, D., Edwards, P., \& Birkin, F. (2001). Some Evidence on Executives' Views of Corporate Social Responsibility. British Accounting Review, 33, 357-397. http://dx.doi.org/10.1006/bare.2001.0165

Yekini, K. C. (2012). Corporate Community Involvement Disclosures: An Evaluation of the Motivation and Reality. PhD Thesis, De Montfort University, Leicester, United Kingdom.

Yekini., K., \& Jallow, K. (2012). Corporate Community Involvement Disclosures in Annual Reports. Sustainability Accounting, Management and Policy Journal, 3(1), 7-32.

\section{Appendix A}

\section{Guide to the Structured Interview Questions}

\subsection{Motivation for Sustainability Reporting}

- What forms of environmental disclosure does your organization engage in?

- What is your corporate motivation for disclosure or non disclosure?

- What is your understanding of sustainability reporting and from your point of view, is this a key practice of your organization?

- What audience is your disclosure targeted at?

- How would you categorize the cost of disclosure relative to its overall benefit?

- Can you briefly elaborate the most important themes under which you report (community, environment, employee, product quality, profit etc).

2.0 Responsibility Hierarchy for Sustainability Reporting

- Within your organization, who is responsible for sustainability reporting and who does this officer report directly to.

- Would you say from personal observation that the senior management of your organization takes sustainability reporting as an integral part of the organizations business?

- Briefly tell us how the data gathering and reporting framework of your organization transpires through the sustainability reporting teams.

3.0 People

- How would you classify your organizations operations relative to the community in which you operate, would you say the activities are exploitative, neutral or beneficial to the community?

- $\quad$ Benevolent activities such as the provision of health care, schools, educational scholarships, transport networks, recruitment of locals etc has been sited in literature as avenues through which corporate entities can return some value to the communities in which they operate, would you be able to identify as a corporate entity with any or all of these forms of benevolence within your community of operation?

- $\quad$ Are there any other forms of people oriented activities your organization carries out in order to maintain a balance between shareholder wealth maximization and stakeholder interest? 


\subsection{Planet}

- In recent times, the politically sensitive issue of environmental protection has been somewhat high up on the agenda of corporate governance discussions, briefly tell us how your company ensures that the by-products of your production does not constitute harmful material to the communities in the catchment area of your operations.

- Oil spillages have been a major concern within the Nigerian Niger Delta, can you enlighten us from the point of view of an insider the likely sources of these oil spillages?

- What role do you perceive your organization plays in mopping up these spillages.

- $\quad$ From your perception as a management staff, what impact do you think these spillages will have on the long term health of the communities downstream?

- Do you consider that enough is being done both by the oil companies operating in this region and the Federal Government of Nigeria to protect the long term health of these communities as a result of the side effect of oil exploration?

\subsection{Profits}

- $\quad$ Can you indicate in monetary or percentage terms what proportion of your company's total profit is set aside as a policy recommendation to ensure that the company's operational footprint on the neighbouring communities is wiped out?

- How will you place your company in terms of this proportion of profit relative to other companies operating within the Niger Delta area?

- Would you say this contribution of profit to the community is sufficient, just okay or inadequate?

6.0 General Views

- $\quad$ Please give us any additional views you may have regarding sustainability reporting within the Nigerian Niger Delta.

\section{Copyrights}

Copyright for this article is retained by the author(s), with first publication rights granted to the journal.

This is an open-access article distributed under the terms and conditions of the Creative Commons Attribution license (http://creativecommons.org/licenses/by/3.0/). 